\title{
The Leadership Approaches by Football Coaches That Are Favored by the Profesional Football Players in Malaysia
}

\author{
Muhammad Rijal Fikry Yusoff, Tajul Arifin Muhamad \\ Faculty of Education, National University of Malaysia, Bangi, Selangor, Malaysia \\ Email: muhammadrijalfikryy@gmail.com
}

How to cite this paper: Yusoff, M. R. F., \& Muhamad, T. A. (2018). The Leadership Approaches by Football Coaches That Are Favored by the Profesional Football Players in Malaysia. Creative Education, 9, 2341-2349. https://doi.org/10.4236/ce.2018.914174

Received: August 16, 2018

Accepted: October 28, 2018

Published: October 31, 2018

Copyright ( $\odot 2018$ by authors and Scientific Research Publishing Inc. This work is licensed under the Creative Commons Attribution International License (CC BY 4.0).

http://creativecommons.org/licenses/by/4.0/

Open Access

\begin{abstract}
This research studies the leadership approaches by football coaches that are favored by professional football players in Malaysia based on age, race and league level. A total of 100 professional players aged between 20 and 40 years in Malaysia were selected using a purposive sampling method. The Leadership Scale for Sports (LSS) questionnaire developed (Chelladurai \& Saleh, 1980) has been used to identify the style of coaching leadership in favor of professional footballers in Malaysia based on age, race and league level. This questionnaire was used to measure the five dimensions of leadership approaches namely training and instruction dimension (12 questions), democratic dimension (10 questions), autocratic dimension (6 questions), dimension of social support (6 questions) and positive feedback dimension (6 questions). The results of the descriptive study show that the players are more interested in democratic dimension leadership approach and the less desirable is the autocratic dimension leadership approach. T-test shows that there is no significant age-based difference in the leadership style of a coach who is interested by professional football players in Malaysia with the value of $p>0.05$ $(t=0.14)$. T-test also showed that there was no significant difference based on the level of the league for the coach's approach that is favored by professional footballers in Malaysia with a value of $p>0.05(t=1.20)$. The Kruskal-Wallis Test shows that there is no significant difference between races in all dimensions of leadership style with $p>0.05$ values. This study has showed that democratic leadership approach is most favored by football players based on age, race and league level.
\end{abstract}

\section{Keywords}

Leadership Approaches, Football Coaches, Football Players, Dimensions of Leadership, League Level 


\section{Introduction}

The current leadership approaches in coaching have become a subject of increasingly attentive research among sports players both inside and outside the country. This is due to the leadership in coaching that can improve harmony, direction and goal formation in a team. Leadership from coaches can influence the success of an athlete at various stages whether low or high and is influenced by various factors such as intrinsic factors, moral support, performance, personality, skill and coach leadership approach (Shaharudin, 2005).

A coach is also able to influence, set the focus, change the interest and also provide the athlete's needed according to (Anuar \& Dolorine, 2013), in terms of leadership style of coach, an effective coach will definitely influence the situation, environment, personality and athlete's attitude towards the burden of duties and responsibilities given by the coach. This may indirectly improve the motivation and performance of athletes thereby giving intrinsic satisfaction to the athlete. For each coach or team manager, when interacting with athletes either while managing training programs, during the competition or not, it affects trained athletes. The impact of the athlete is directly proportional to the positive relationship between the interactions, between the wishes and the needs of the coach, the team manager with the athlete, the satisfaction and performance of the athlete involved will increase, the athlete will achieve the desired success.

In Malaysia, the issue of leadership approaches in coaching is still lacking in widespread attention, especially among team managers in terms of professional trainer selection. Looking at the quality factor and quality of the sports industry in the country that can be classified as low and unsatisfactory, such a study should be done as the leadership applied and carried by the coach is crucial in influencing the training environment, the psychology of the athlete's guidance and can influence the success of a team leader. Based on previous studies, it was found that the behavior of coaches in Malaysia was less studied (Institut Sukan Negara, 2014; Soh, Wazir, \& Chee, 2014). Many researchers have conducted various studies related to motivation, training and instruction and achievements (Kaynaka, Canb, Kirandic, \& Boz, 2014; Martin, Dale, \& Jackson, 2001; Samah, Adekalu, Omar, \& Ismail, 2013; Samah, Omar, \& Osman, 2015; Shokri, Viladrich, Cruz, \& Alcaraz, 2014). This situation also provides information that trainer behavior is often less taken into account as a matter of urgency in coaching programs.

\section{Theory and Concept}

\subsection{Leadership Concepts}

Leadership is defined as a form of capable behavior and has the ability to change the direction of an organization. Leadership must choose certain criteria in order to meet and achieve the objectives set by the organization's besides the leader can monitor the actions of subordinates so that they can be selected according to 
the criteria for the development and success than capable of forming and maintain a strong teamwork. Leadership is a difficult and complex concept (Stogdill, 1974). Stodgill's view of leadership is a comprehensive or universal human phenomenon and extremely difficult to understand (Stogdill, 1974). Hollander described leadership as a process of influence among leaders and followers (Hollander, 1978). Although leaders have the power but influence is more depends on persuasion rather than compulsion. Leadership processes usually involve ties in two-way influences and their primary purpose is to achieve common goals.

\subsection{Theory of Sports Coaching}

According to a questionnaire developed through a multidimensional theory of leadership coaching conducted by them, Leadership Scale for Sports (LSS), researchers have divided the coaching leadership theory into five namely Democratic Dimension, Autocratic Dimension, Training and Instruction Dimension, Social Support Dimensions and the last is the Positive Feedback Dimension (Chelladurai \& Saleh, 1980). The purpose of this multidimensional theory of coaching leadership is to understand and identify the characteristics of coaching leadership inherent in sports and integrate leadership theories as well as to determine whether certain particular leadership theories fit or not to be applied to the sports environment.

\subsection{Democratic Dimension}

Leadership behaviors emphasize the involvement of athletes in decision making, including organizational goals, training program and game strategies. The coach in this dimension encourages all his athlete's guidance to engage in the organization and always give each athlete an opportunity to give an opinion before a decision is taken.

\subsection{Autocratic Dimensions}

Leadership behaviors that emphasize absolute power to coaches with full emphasis on authority. The autocratic coach is a trainer who cares for the full implementation of his duties and responsibilities without altering any change or requesting an opinion from his athlete's guidance.

\subsection{Training and Instructions Dimensions}

Leadership behavior emphasizes on improving performance through training and tutoring to facilitate techniques, skills and tactics in sports. This coach is a fraction of the autocratic dimension but is considered more humane and his leadership is softer and friendly but very detailed and neat. Coaching from this dimension highlights the planned training program as planned and the athlete can practice according to the set training capacity.

\subsection{Social Support Dimensions}

Leadership behaviors are concerned with the athlete's welfare, positive team 
group environment and good interpersonal relationships between coaches and athletes. This coach practices a coaching leadership style that cares about matters related to athletes. The coaches in this dimension are so familiar with the welfare of athletes and also help solve the athlete's personal problems. The coaches are also ready to help solve problems in the team as if there were conflicts between team members.

\subsection{Positive Feedback Dimension}

Leadership behaviors emphasize the strengthening of athlete's attitudes with appropriate feedback with recognition and rewarding in the form of rewards to help improve athlete's achievement. Coaches that practice this positive feedback dimension give the athlete a compliment if the athlete exhibits their skills and likes to make the athlete skilled as an example to his other teammates.

\section{Research Methodology}

This study is a quantitative study using the survey method. The survey method is a very appropriate and widely used method in educational research. The survey method involves the process of providing questionnaires, citing data and finally analyzing the data. The use of survey methods enables the study to obtain simplified data easily and effectively.

\subsection{Sample of Study}

In this study, respondents consisted of football players who signed the contract as a professional player for the 2018 season. These players consist of players in the Super League and Premier League. A total of 108 players were selected as respondents.

\subsection{Data Collection}

In this study, the researcher selected the questionnaire as an appropriate instrument for collecting respondents' data to obtain information about the style of leadership that the professional football players are interested in. In this study, the researcher chose the Leadership Scale for Sports (LSS) questionnaire (Chelladurai \& Saleh, 1980) which consists of 40 Likert scaled questions to test the 5 dimensions of coach leadership style i.e. training and instruction dimensions (12 questions); democratic dimension (10 questions); autocratic dimension (6 questions); social support dimensions (6 questions) and positive feedback dimensions (6 questions).

\section{Results and Discussions}

Part A in the questionnaire is related to the background of respondents such as age, race and league level of respondents. Respondents are required to mark the parts that have been directed. All data on the respondents' background are shown in Table 1. 
In Table 1, respondents were divided into two groups of ages: 20 - 30 years and 31 - 40 years old. There were 67 respondents aged 20 - 30 years (67\%) and 33 respondents aged 31 - 40 years (33\%). In the meantime, in terms of race, 62 players (62\%) are Malays, 30 players (30\%) are Indian, 5 players (5\%) are Chinese and 3 players (3\%).

Based on the league level, 50 players (50\%) are players in the Super League and 50 players (50\%) from the Premier League.

Table 2 shows leadership style data favored by professional football players in Malaysia. The player prefer the democratic dimension $(\min =3.94$, $\mathrm{SP}=0.65)$, followed by training dimension and instruction $(\mathrm{min}=3.61, \mathrm{SP}=0.64)$, social support dimension $(\min =3.53, \mathrm{SP}=0.90)$ and dimensions that are not favored are autocratic dimensions $(\min =1.81, \mathrm{SP}=0.92)$.

Table 3 shows the style of leadership favored by professional football players in Malaysia based on age. (Min $=3.69, \mathrm{SP}=0.76$ ), followed by training and instruction dimension $(\mathrm{min}=3.48, \mathrm{SP}=0.69)$, social support dimension $(\mathrm{min}=$ $3.47, \mathrm{SP}=0.83)$, the feedback dimension $(\mathrm{min}=3.46, \mathrm{SP}=0.83)$ and the least favored dimensions of players 20 - 30 years are autocratic dimensions (mean = $2.11, \mathrm{SP}=0.94)$. The results of the study showed that the 31-40 year players favored the democratic dimension $(\mathrm{min}=4.12, \mathrm{SP}=0.47)$, followed by training and instruction dimensions $(\mathrm{min}=3.70, \mathrm{SP}=0.59$ ), social support dimensions $($ mean $=3.58, \mathrm{SP}=0.93)$, the feedback dimension $(\min =3.34, \mathrm{SP}=0.68)$ and

Table 1. Background of respondents.

\begin{tabular}{cccc}
\hline Background Respondents & N & \% \\
\hline Age & $20-30$ years old & 67 & 67 \\
& $31-40$ years & 33 & 62 \\
Races & Malay & 62 & 30 \\
& India & 30 & 5 \\
& Chinese & 5 & 3 \\
Stage league & Others & 3 & 50 \\
& Super League & 50 & 50 \\
\hline
\end{tabular}

Table 2. Raw data of leadership styles that are interested in professional soccer players in Malaysia.

\begin{tabular}{cccccc}
\hline & \multicolumn{5}{c}{ Dimensions Leadership } \\
\cline { 2 - 6 } Variable & $\begin{array}{c}\text { Training \& } \\
\text { Instructions }\end{array}$ & Democratic & Autocratic & $\begin{array}{c}\text { Support } \\
\text { Social }\end{array}$ & $\begin{array}{c}\text { Positive } \\
\text { feedback }\end{array}$ \\
\hline Player & 3.61 & 3.94 & 1.81 & 3.53 & 3.39 \\
Min & 0.64 & 0.65 & 0.92 & 0.90 & 0.75 \\
SP & 100 & 100 & 100 & 100 & 100 \\
N & & & & & \\
\hline
\end{tabular}


Table 3. Raw data of leadership styles that are interested in professional footballers in malaysia based on age.

\begin{tabular}{cccccc}
\hline \multirow{2}{*}{ Variable } & \multicolumn{5}{c}{ Dimensions Leadership } \\
\cline { 2 - 6 } & $\begin{array}{c}\text { Training \& } \\
\text { Instructions }\end{array}$ & Democratic & Autocratic & $\begin{array}{c}\text { Support } \\
\text { Social }\end{array}$ & $\begin{array}{c}\text { Positive } \\
\text { feedback }\end{array}$ \\
\hline $20-30$ years old & & 3.69 & 2.11 & 3.47 & 3.46 \\
Min & 3.48 & 0.76 & 0.94 & 0.83 & 0.87 \\
SP & 0.69 & 67 & 67 & 67 & 67 \\
N & 67 & & & & \\
$31-$ 40 years & 3.70 & 4.12 & 1.58 & 3.58 & 3.34 \\
Min & 0.59 & 0.47 & 0.84 & 0.93 & 0.68 \\
SP & 33 & 33 & 33 & 33 & 33 \\
N & & & & \\
\hline
\end{tabular}

the dimensions of the least favored player 31 - 40 years is the autocratic dimen$\operatorname{sion}(\min =1.58, \mathrm{SP}=0.84)$.

Table 4 shows leadership styles favored by professional football players in Malaysia based on race. In this study, the Malay players prefer the democratic dimension $(\mathrm{min}=3.94, \mathrm{SP}=0.68)$, followed by training and instruction dimensions $(\min =3.63, \mathrm{SP}=0.68)$, feedback dimension $(\mathrm{min}=3.41, \mathrm{SP}=1.06)$ social $(\mathrm{min}=3.28, \mathrm{SP}=0.82)$ and the dimensions most preferred by the Malay players are autocratic dimensions $(\min =1.69, \mathrm{SP}=0.85)$. The findings of the next study show that Indian players love the dimensions of training and instruction $(\mathrm{min}=$ 3.88, $\mathrm{SP}=0.61)$, followed by democratic dimension $(\mathrm{min}=3.59, \mathrm{SP}=0.65)$, feedback dimension $(\min =3.50, \mathrm{SP}=0.85)(\min =3.45, \mathrm{SP}=0.75)$ and the dimensions most liked by Indian players are autocratic dimensions $(\mathrm{min}=1.87$, $\mathrm{SP}=0.96)$. Meanwhile, for the Chinese Dusun, this player $(\min =4.38, \mathrm{SP}=$ $0.34)$, followed by feedback dimension $(\min =4.17$, $\mathrm{SP}=0.62)$, training dimension and instruction $(\mathrm{min}=3.76, \mathrm{SP}=0.44)$, social support dimension $(\mathrm{min}=$ $3.48, \mathrm{SP}=0.38$ ) and the dimensions most favored by Chinese players are autocratic dimensions ( $\min =1.55, \mathrm{SP}=0.55)$. The findings of the next study showed that players from other races also favored the democratic dimension ( $\mathrm{min}=$ $4.03, \mathrm{SP}=0.97)$, followed by feedback dimension $(\mathrm{min}=3.75, \mathrm{SP}=0.59)$, social support dimension (mean $=3.71, \mathrm{SP}=0.61$ ), the dimensions of training and instruction $(\min =3.55, \mathrm{SP}=0.53)$ and the dimensions most liked by this race are autocratic dimensions (mean $=2.65, \mathrm{SP}=1.68$ ).

Table 5 shows the raw data of leadership style favored by professional football players in Malaysia based on league level. ( $\mathrm{Min}=3.65$, SP $=0.71$ ), followed by feedback dimension $(\mathrm{min}=3.59, \mathrm{SP}=0.88)$, training dimension and instruction $(\min =3.57, \mathrm{SP}=0.68)$, dimension Social support $(\min =3.55, \mathrm{SP}=0.80)$ and the dimensions most preferred by Super League players are autocratic dimensions $(\min =2.37, \mathrm{SP}=0.95)$. The results of the study showed that the Premier 
Table 4. Raw data of leadership styles that are interested in professional footballers in Malaysia based on age.

\begin{tabular}{cccccc}
\hline \multirow{2}{*}{ Variable } & \multicolumn{5}{c}{ Dimensions Leadership } \\
\cline { 2 - 6 } Malay & Training \& Instructions & Democratic & Autocratic & Social & Positive feedback \\
Min & 3.63 & 3.94 & 1.69 & 3.28 & 3.41 \\
SP & 0.68 & 0.67 & 0.85 & 0.82 & 1.06 \\
N & 62 & 62 & 62 & 62 & 62 \\
India & & & & & \\
Min & 3.88 & 3.59 & 1.87 & 3.45 & 3.50 \\
SP & 0.61 & 0.65 & 0.69 & 0.75 & 0.85 \\
N & 30 & 30 & 30 & 30 & 30 \\
Chinese & & & & & \\
Min & 3.76 & 4.38 & 1.55 & 3.48 & 4.17 \\
SP & 0.44 & 0.34 & 0.55 & 0.38 & 0.62 \\
N & 5 & 5 & 5 & 5 & 5 \\
Others & 3.55 & 4.03 & 2.65 & 3.71 & 3.75 \\
Min & 0.53 & 0.97 & 1.68 & 0.61 & 0.59 \\
SP & 3 & 3 & 3 & 3 & 3 \\
N & & & & & 5 \\
\hline & & & & & \\
\hline
\end{tabular}

Table 5. Raw data of leadership styles who are interested in professional soccer players in malaysia based on league level.

\begin{tabular}{cccccc}
\hline \multirow{2}{*}{ Variable } & \multicolumn{5}{c}{ Dimensions Leadership } \\
\cline { 2 - 6 } & $\begin{array}{c}\text { Training \& } \\
\text { Instructions }\end{array}$ & Democratic & Autocratic & $\begin{array}{c}\text { Support } \\
\text { Social }\end{array}$ & $\begin{array}{c}\text { Positive } \\
\text { feedback }\end{array}$ \\
\hline $\begin{array}{c}\text { Super League } \\
\text { Min }\end{array}$ & 3.57 & 3.65 & 2.37 & 3.55 & 3.59 \\
SP & 0.68 & 0.71 & 0.95 & 0.80 & 0.88 \\
N & 50 & 50 & 50 & 50 & 50 \\
League Prime & & & & & \\
Min & 3.64 & 4.23 & 1.24 & 3.24 & 3.47 \\
SP & 0.60 & 0.40 & 0.42 & 0.66 & 0.93 \\
N & 50 & 50 & 50 & 50 & 50 \\
\hline
\end{tabular}

League players also favored the democratic dimension $(\min =4.23$, SP $=0.40)$, followed by training and instruction dimensions $(\min =3.64, \mathrm{SP}=0.60)$, feedback dimensions $(\mathrm{min}=3.47, \mathrm{SP}=0.93)$ social support $(\mathrm{min}=3.24, \mathrm{SP}=0.66)$ and the least favored dimensions of the Premier League players are autocratic dimensions $(\min =1.24, \mathrm{SP}=0.42)$. 


\section{Discussions}

Leadership approaches give a very important role to the leader's relationship with his followers in the leader's efforts to control the situation in organizational goals and objectives (Fiedler, 1967). The overall study finds that the leadership style most preferred by professional football players in Malaysia is the democratic dimension and the least disliked is the autocratic dimension.

On the aspect of comparison of the leadership style of coach who is interested in professional football players in Malaysia based on age, it is found that there is no significant difference in the style of coach leadership style that players are interested in based on age. This shows that age differences do not affect their assessment of the style of leadership professed by professional football players in Malaysia.

On the aspect of comparison of the leadership style of the coach who is interested in race based on race, it is found that there is no significant difference in the comparison of the style of coach leadership that is most interested in racial players. This shows that racial differences do not affect their assessment of the style of leadership that the professional football players in Malaysia are interested in.

For the comparison aspect of coach leadership style that players are interested in based on the league level, there is no significant difference in comparison to the style of coach leadership that players are interested in based on the league level. This shows the difference in level of league is not influencing their assessment of the style of leadership that the professional football players in Malaysia are interested in. From the research and discussion, it can be concluded that:

1) The results of this study show that the leadership style is the most desirable professional football players in Malaysia as a whole and based on age, race and league, levels are the same in democratic dimensions.

2) While the less desirable by professional football players in Malaysia is autocratic dimension.

3) Factors of age difference, race and league level indicate that it does not influence coach leadership style.

\section{Conflicts of Interest}

The authors declare no conflicts of interest regarding the publication of this paper.

\section{References}

Anuar, D., \& Dolorine, M. (2013). Pengaruh Gaya Kepimpinan Jurulatih TerhadapKepuasan Atlet Di Sekolah Sukan Malaysia. Jurnal Kajian Pendidikan, 3, 195-210.

Chelladurai, P., \& Saleh, S. D. (1980). Dimension of Leadership Behavior in Sports: Development of a Leadership Scale. Journal of Sports Psychology, 2, 34-35. https://doi.org/10.1123/jsp.2.1.34

Fiedler, F. E. (1967). A Theory of Leadership Effectiveness. New York: McGraw-Hill.

Hollander, E. P. (1978). Leadership Dynamics. New York: Free Press. 
Institut Sukan Negara. (2014). Research Committee Report: 2012-2013. Kuala Lumpur: Institut Sukan Negara.

Kaynaka, K., Canb, Y., Kirandic, O., \& Boz, M. (2014). Examination of the Relationship between Role Satisfaction and Achievement Motivation among Players: A Research on Veteran National Players. Procedia-Social and Behavioral Sciences, 152, 465-469. https://doi.org/10.1016/j.sbspro.2014.09.232

Martin, S. B., Dale, G. A., \& Jackson, A. W. (2001). Youth Coaching Preferences of Adolescent Athletes and Their Parents. Journal of Sport Behavior, 24, 197-212.

Samah, I. H. A., Adekalu, S. O., Omar, Z., \& Ismail, I. A. (2013). Influence of Coaches' Behavior on Athletes' Motivation: Malaysian Sport Archery Experience. International Journal of Research in Management, 5, 136-142.

Samah, I. H. A., Omar, Z., \& Osman, A. (2015). An Investigation of Athletes' Satisfaction towards Teammates and Its Relationship with Athletes' Intrinsic Motivation. International Journal of Science: Basic and Applied Research (IJSBAR), 20, 349-355.

Shaharudin, A. A. (2005). Perkaitan antara matlamat dan stail kepimpinan dengan pencapaian atlet Sukma Negeri Perak Di Kejohanan Sukma 2004. eWacana Penyelidikan UPSI, 13.

Shokri, A., Viladrich, C., Cruz, J., \& Alcaraz, S. (2014). Adapting BRSQ to Assess Coach's Perception of Athletes' Motivation: Internal Structure Analysis. Procedia-Social and Behavioral Sciences, 159, 497-505. https://doi.org/10.1016/j.sbspro.2014.12.413

Soh, K. G., Wazir, M. R., \& Chee, C. S. (2014). Kajian sukan di Malaysia (Jilid 2). Selangor: Penerbit Universiti Putra Malaysia.

Stogdill, R. M. (1974). Handbook of Leadership, a Survey of Theory and Research. New York: The Free Press. 